\title{
Sauropus androgynus, Papaya Leaves, and Mung Beans as Mixed Galactagogue Drink for Urban Postpartum Mothers
}

\author{
Iskari Ngadiarti ${ }^{1}$, Lina Agestika ${ }^{2 *}$, Mia Srimiati ${ }^{2}$, Adhila Fayasari ${ }^{2}$ \\ ${ }^{1}$ Department of Nutrition, Health Polytechnic Ministry of Health Jakarta II, Jakarta 12120, Indonesia \\ ${ }^{2}$ Department of Nutrition, Faculty of Health Sciences and Technology, Binawan University, \\ Jakarta 13630, Indonesia
}

\begin{abstract}
This study explored the effect of Sauropus androgynus, papaya leaves, and mung beans as mixed galactagogue drinks on breastmilk volume, frequency, and duration among urban postpartum mothers in Jakarta. A quasi-experimental study with 60 postpartum mothers divided in intervention and control groups was conducted. The intervention group was administered with a 400-cc traditional galactagogue drink daily within 4 weeks of postpartum, while the control group received 3 times breastfeeding counselling. The breastmilk volume was measured using the evaporative water loss method on mothers' weight at the first, second, third-, and fourth-week consumption. The mean difference of breastmilk volume, breastfeeding frequency, and duration between the intervention and control groups was calculated by bivariate analysis using an independent sample t-test. The breastmilk volume was not different between both groups on the first and second week $\left(1^{\text {st }}: 622.93 \pm 289.24\right.$ and $507.68 \pm 231.28$, $\mathrm{p}=0.094 ; 2^{\text {nd }}: 683.00 \pm 252.42$ and $\left.582.58 \pm 225.42, \mathrm{p}=0.110\right)$, however, the intervention group had higher volume than the control group in the third and fourth week $\left(3^{\text {rd }}: 801.43 \pm 273.35\right.$ and $656.24 \pm 214.43$, $\mathrm{p}=0.026 ; 4^{\mathrm{th}}=908.52 \pm 271.27$ and $756.69 \pm 196.29, \mathrm{p}=0.016$ ). No significant difference was observed in the breastfeeding frequency and duration among the groups. In conclusion, the new galactagogue mixed drink consumption has the potential to increase breastmilk production and enhance a mother's confidence to continue breastfeeding.
\end{abstract}

Keywords: breastfeeding, counselling, mung beans, polyphenol, Sauropus androgynous

\section{INTRODUCTION}

One of the global nutrition targets in Sustainable Development Goals (SDGs) is to promote the rate of mothers performing exclusive breastfeeding within 6 months up to at least 50\% in 2025 (Fanzo et al. 2018). However, the proportion of $0-5$ months old infants fed exclusively with breast milk has only been $40.7 \%$ and formula milk sales in developing countries are increasing gradually (Fanzo et al. 2018). In Indonesia, the exclusive breastfeeding rate is $37.3 \%$ (MoH RI 2018), despite the country's effort to follow the World Health Organization (WHO) recommendation and issued a Decree from the President of Republic Indonesia No.33/2012 which stipulated child feeding practices which included exclusive breastfeeding for the first 6 months of life.

Exclusive breastfeeding is essential for optimal child growth and development
(Kuchenbecker et al. 2015). Inadequate practices of this contribute to more than ten thousand mother's and children's deaths yearly (Walters et al. 2016). While adequate practice can prevent both communicable and non-communicable diseases such as diarrhoea, pneumonia, and cancer (Walters et al. 2016). Breast milk nutritional composition correlates with the baby's physiological states and immune system to prevent infection and reduce risk of obesity (Tao et al. 2017; Sakka 2014). Furthermore, breastfeeding also provides comfort which bridges the differences between pre and postnatal life for infants, acted as a natural contraception for mothers and reduces risk of maternal cancers of reproductive organs (Newton 2018; Sakka 2014).

Commonly identified barriers on providing exclusive breastfeeding are identified i.e anxiety of inadequate production, premature delivery, serious medical concern, separation

\footnotetext{
"Corresponding Author: tel: +6281213593565, email: lina.agestika@binawan.ac.id (Received 17-05-2021; Accepted 30-06-2021; Published 29-07-2021)
} 
from the baby after birth, stress, and discomfort (Sakka 2014). Previous study reported that 38\% of mothers stopped breastfeeding due to a lack of breast milk (Ghasemi et al. 2015). The two weeks after delivery are critical to determining the success of breastfeeding; since the mother may feel fatigued and painful nipples, at the same time the baby shows dissatisfaction with breast milk. Evidence proved that in the 48 hours after delivery, the infants often experience reduced weight, showed satiety rather than sleep well, produced insufficient urine and stool (Galipeau et al. 2017). These conditions can lead to anxiety and lack of self-confidence among mothers on their capacity to exclusively breastfeed their infants. Therefore, many preferred to either consume galactagogue or attend the counselling to improve their milk production and to smoothen the exclusive breastfeeding process especially for those that have delivered the first child (Nguyen et al. 2016; Foong et al. 2020).

One of the local wisdoms were elders or family providing treatment such as massage, acupuncture, herbal therapy meditation, and yoga for postpartum mothers especially for those living in the rural area. Through those, the mother could face easy post-delivery period and an easy breastfeeding (Mediastari 2020). Supporting the treatment, several food ingredients are expected to give a lactogenic effect including Sauropus androgynous or known locally as "katuk leaves" and papaya leaves. Sauropus androgynous is a potential commodity easily found in Indonesia, so far many Indonesian people had experienced the benefits, but the scientific evidence to measure its effect on breastmilk volume are still scarce (Indrayani et al. 2020; Santoso 2016; Suwanti \& Kuswanti 2015; Pinem et al. 2019). Supplements containing these ingredients have been consumed among Indonesian mothers to increase breast milk production (Suwanti \& Kuswati 2015). Furthermore, papaya leaves juice and mung beans also affect breastfeeding (Wulandari \& Jannah 2015).

Mothers who livein a rural area that adhering tradition and whose education was lower and were unemployed have a higher rate of exclusive breastfeeding compared to working and educated mothers. In addition, mothers living in Jakarta have the lowest rate of exclusive breastfeeding practice compared to other provinces (Laksono et al. 2021). Further, there has been misconception on food containing galactagogue among urban mothers, they perceive it did not bring benefit to breastmilk production, while formula milk consumption brought healthier effect to baby due to heavier weight gain (Nuzrina et al. 2016). A dilemma of lactating mothers when they should return to work and leave their babies at home is also a common reason among urban mothers to stop breastfeeding (Sulaiman et al. 2018). Previous study stated that counselling through interpersonal discussion brought a more positive outcome on breastfeeding behaviour than only receiving a campaign through mass media (Nguyen et al. 2016). Finding professionals and receiving a recommendation from experts help to determine successful breastfeeding (Nyqvist et al. 2012). However, for some parents counselling can be burdensome due to the cost and time required. Thus, effective galactagogue may help to ease the burden or supplement the breastfeeding counselling when needed. Therefore, this study aims to compare the breastmilk volume, breastfeeding frequency, and duration after the administration of mixed galactagogue drink and receiving counselling only among urban postpartum mothers.

\section{METHODS}

\section{Design, location and time}

This study used a quasi-experimental design where two groups were assigned with random selection. It was conducted at the Maternity Home Integrated Primary Health Centre (Puskesmas) Kebayoran Lama District from August to November 2017. This was approved by the Ethical Review Committee for Human Research Health Polytechnic of Jakarta II under NO. LB.02.01/I/KE/31/287/2017.

\section{Sampling}

The inclusion criteria were healthy pregnant women in the third trimester with age range 20-35 years, not smoking, with a single pregnancy, routinely attended antenatal care, and voluntarily involved in this study. Mothers were excluded when she had serious medical conditions, food allergy, and drank other galactagogue supplements besides what was administered. All participants received an explanation of the study procedures and signed an informed consent form beforehand. In total, 60 
pregnant mothers were recruited and randomly assigned into the intervention and control groups.

\section{Data collection}

Data including the respondents' age, education, occupation, household income, mother's weight and height were collected to determine the nutritional status using Body Mass Index (BMI) with the formula weight $(\mathrm{kg}) /$ height $\left(\mathrm{m}^{2}\right)$. Their body weights were measured before and after breastfeeding, while the frequency and duration were also recorded using the recall method.

The breastmilk volume measurement was performed using the evaporative water loss method on the participants at the first, second, third, and fourth week of postpartum. The mothers' weight was measured before and immediately after breastfeeding using an electronic weighing scale with +5 g accuracy (Tanita HD-378-Digital Scale) as also mentioned in the previous study (Scanlon et al. 2002). In addition, the compliance level of mixed drink consumption was recorded on the observation sheet. Information on a 24hour breastfeeding frequency and duration was also collected through interviews.

Galactagogue Mixed Drink (GMD). The galactagogue mixed drink ingredients were Sauropus androgynous extract, mung beans, papaya leaves, tamarind, sugar and water. The first step is shorting the desirable Sauropus androgynous and papaya leaves which were neither too old nor too young, with fresh green colour, then washed them with clean water. The composition of one serving are $50 \mathrm{~g}$ Sauropus androgynous, 25 g Papaya leaves, 15 g mungbeans, $15 \mathrm{~g}$ sugar, $25 \mathrm{~g}$ tomatoes and 12 $\mathrm{g}$ tamarind. Second, the leaves were blanched at a temperature of $83^{\circ} \mathrm{C}-92^{\circ} \mathrm{C}$ for 3 minutes. After that, each Sauropus androgynous and papaya leaves were formed into a solution using a blender with leaves and water proportion were 1:2.

The solution was then filtered and mixed with mung bean porridge, sugar, and tamarind. Then it was heated to $60^{\circ} \mathrm{C}$ for 15 minutes. The mixed galactagogue drink is cooled at room temperature and the products were packaged into a ready-to-drink bottle with the same shape, size and packaging material. The nutrient and polyphenol contents per 100 grams are calorie $(57.0 \mathrm{Cal})$, protein $(0.9 \mathrm{~g})$, fat $(0 \mathrm{~g})$, carbohydrate $(13.5 \mathrm{~g})$, water $(85.3 \mathrm{~g})$, ash $(0.3 \mathrm{~g})$, fiber $(0.5 \mathrm{~g})$, and polyphenol $(574 \mathrm{mg}$ ).
Intervention group. The intervention groups were administered $400 \mathrm{cc}$ mixed Sauropus androgynous leaf extract, papaya leaves, mung bean and turmeric mixed drink products $(2$ bottles) daily for 4 weeks of postpartum. One bottle of mixed drink $( \pm 200 \mathrm{ml})$ was consumed twice daily within the interval of the main meal and at night before sleeping. The participants started consuming the galactagogue drink immediately after delivery until the fourth week of exclusive breastfeeding.

Control group. Breastfeeding counselling was delivered for 30-45 minutes thrice after delivery within 2 months of observation (at birth, 7-14, and 35 days old). The material used in this process referred to the module from the Ministry of Health's 40-hour by a health worker or enumerator that had attended such counselling before. Mother's weight measurement to determine the breastmilk volume, breastfeeding frequency and duration was performed for the intervention group during counselling at the first, second, third and fourth week of postpartum. Before the intervention started, a socio-economic and nutritional intake screening process through $2 \times 24$ hours food recalled was performed to ensure that both groups had the similar characteristics.

\section{Data analysis}

All data were coded and analysed using SPSS software version 21. The univariate statistical analysis was used to determine the mean, median, and Standard Deviation (SD) for continuous variable. Participant's characteristics were analysed using chi-square test to ensure both groups having similar characteristics to prevent bias. The mean difference of breastmilk volume, breastfeeding frequency and duration between the intervention and control groups was calculated by bivariate analysis using independent sample t-test. The statistical result with a $p<0.05$ was considered significant. The mean difference of breastmilk volume between $1^{\text {st }}$ and $2^{\text {nd }}$ week, $2^{\text {nd }}$ week to $3^{\text {rd }}$ week, and $3^{\text {rd }}$ week and $4^{\text {th }}$ week in both groups were analysed using independent sample t-test.

\section{RESULTS AND DISCUSSION}

\section{Characteristics of respondents}

The characteristics of participants can be seen in Table 1 . The majority were aged $21-30$ years old, finished senior high school, housewives 
and from higher-income family with 2,000,000 IDR monthly income in both groups, indicating no significant differences in this aspect $p>0.05$ (Table 1). The mean value of BMI in both groups was normal but near to overweight. In addition, infants' characteristics distribution was almost equal across genders with mostly had a term delivery and normal birth weight.

\section{Breastmilk volume, breastfeeding frequency and duration}

Breastfeeding practice is essential to child immunity against mild and severe infections, therefore, when mixed or non-exclusive it leads to higher risk (Tao et al. 2017). Supporting and facilitating the process tend to make it successful. This study analysed how mixed galactagogue drink and counselling influenced the exclusive breastfeeding practice among urban postpartum mothers. The result showed that rather than counselling, consuming galactagogue drink was more effective at increasing the breastmilk volume. The mean breastmilk volume in the third and fourth week after GMD consumption among the intervention group was higher than the control which was $801.4 \pm 273.3$ and $908.5 \pm 271.3$ $\mathrm{ml} /$ day, respectively. The breastmilk volume in the first week after the intervention was not significantly different from the second week $(p>0.05)$. Compared to the second week, the breastmilk volume is higher in the third week. Another increase was observed from the third to the fourth week among intervention groups $(p<0.05)$. Meanwhile, in the control group, the significant difference was only significant between the third and fourth weeks. Additionally, there was no significant difference between two groups in terms of breastfeeding frequency and duration (Table 2).

Commercial galactagogues consumption was often in the form of supplement or tea (Foong et al. 2020; Ghasemi et al. 2015). This supposed to make it easy-to-drink besides avoiding the unpleasant taste and smells due to the herbal ingredients. However, it is often inaccessible due to the expensive price. Thus, a traditional formulation was used by simply boiling the mixed herbs and vegetables altogether, the GMD can be produced and consumed daily without spending more. Additionally, a mixture of mung beans, tamarind, and a bit of sugar removed the bitter taste and enhanced the product acceptability.
Galactagogue is commonly consumed in the lactogenesis II stage or right after birth, when physiologically the mammary glands start breastmilk secretory activation (Newton 2018; Ghasemi et al. 2015; Foong et al. 2020). In this stage, a normal or delayed production tends to occur, since after placenta removal, progesterone decreases sharply as the prolactin, cortisol, and insulin levels increase (Pillay \& Davis 2020).

The breastmilk volume among the groups increased gradually indicating that due to infant growth, they required more nutrient to stimulate breastmilk ejection (Table 2). Skin to skin contact and nipple stimulation as the infant's tip of the tongue touches the nipple for suckling, the afferent impulses from sensory nerve terminals stimulation in the areolas travel to the central nervous system, hence, promoting oxytocin secretion for breastmilk release (Newton 2018). Earlier and more frequent breastfeeding increases breastmilk production, while other factors such as primiparous women, having a caesarean delivery, retained placental fragments, diabetes, and stressful vaginal deliveries retain its ejection (Pillay \& Davis 2020).

A previous study showed consuming galactagogues within certain periods during postpartum elevated milk productions than a placebo (Nguyen et al. 2016). The breastmilk volume in the second and fourth week was comparable to the previous study that used various natural oral galactagogues such as banana flower, fenugreek, ginger and moringa (Foong et al. 2020). The result showed that the breastmilk volume in this study was higher. This might be because each vegetable mixture used contains nutrients needed to stimulate the ejection process, hence, their combination might bring more galactagogue effects. This result is in agreement with a recent literature review that highlights the robust increment of breastmilk volume after consuming mixed natural oral galactagogues (Foong et al. 2020). Another study used lactating rats as experimental subjects which presented mixed galactagogue responses to increase milk production by regulating Aquaporins (AQP) in the mammary gland especially AQP-3 and AQP5 protein levels which mainly controlled water movement (Liu et al. 2015).

Sauropus androgynus consumption orally after 24 hours of postpartum gave a $50.7 \%$ increase in breastmilk volume and reduced the 
Galactagogue mixed drink for postpartum mothers

Table 1. Characteristics of respondents

\begin{tabular}{|c|c|c|c|c|}
\hline \multirow{2}{*}{ Variable } & \multicolumn{2}{|c|}{ Intervention group $(\mathrm{n}=30)$} & \multicolumn{2}{|c|}{ Control group $(\mathrm{n}=30)$} \\
\hline & $\mathrm{n}$ & $\%$ & $\mathrm{n}$ & $\%$ \\
\hline \multicolumn{5}{|l|}{ Mothers' characteristics ${ }^{\mathrm{a}}$} \\
\hline \multicolumn{5}{|l|}{ Age } \\
\hline$\leq 20$ & 2 & 6.7 & 2 & 6.7 \\
\hline $21-30$ & 18 & 60.0 & 21 & 70.0 \\
\hline $31-40$ & 8 & 26.7 & 6 & 20.0 \\
\hline$\geq 41$ & 2 & 6.7 & 1 & 3.3 \\
\hline \multicolumn{5}{|l|}{ Education } \\
\hline Elementary & 3 & 10.0 & 2 & 6.7 \\
\hline Junior high school & 8 & 26.7 & 8 & 26.7 \\
\hline Senior high school & 18 & 60.0 & 14 & 46.7 \\
\hline Diploma & 0 & 0 & 1 & 3.3 \\
\hline Bachelor degree & 1 & 3.3 & 5 & 16.7 \\
\hline \multicolumn{5}{|l|}{ Occupation } \\
\hline Housewives & 24 & 80.0 & 22 & 73.3 \\
\hline Private company & 5 & 16.7 & 5 & 16.7 \\
\hline Trade & 1 & 3.3 & 1 & 3.3 \\
\hline Entrepreneurs & 0 & 0 & 1 & 3.3 \\
\hline Others & 0 & 0 & 1 & 3.3 \\
\hline \multicolumn{5}{|l|}{ Household monthly income } \\
\hline $500,000-1,000,000$ IDR & 3 & 10.0 & 1 & 3.3 \\
\hline $1,000,000-2,000,000 \mathrm{IDR}$ & 8 & 26.7 & 10 & 33.3 \\
\hline$>2,000,000 \mathrm{IDR}$ & 19 & 63.3 & 19 & 63.3 \\
\hline \multicolumn{5}{|l|}{ Anthropometry } \\
\hline Baseline weight (Mean \pm SD) & \multicolumn{2}{|c|}{$63.7 \pm 12.4$} & \multicolumn{2}{|c|}{$63.1 \pm 7.7$} \\
\hline End-line weight (Mean \pm SD) & \multicolumn{2}{|c|}{$60.3 \pm 13.1$} & \multicolumn{2}{|c|}{$58.6 \pm 7.6$} \\
\hline Height (Mean \pm SD) & \multicolumn{2}{|c|}{$156.4 \pm 5.7$} & \multicolumn{2}{|c|}{$157.6 \pm 4.5$} \\
\hline BMI $($ Mean \pm SD $)$ & \multicolumn{2}{|c|}{$24.5 \pm 4.8$} & \multicolumn{2}{|c|}{$23.5 \pm 2.7$} \\
\hline \multicolumn{5}{|l|}{ Infants' characteristics } \\
\hline \multicolumn{5}{|l|}{ Parity } \\
\hline Child number -1 & 5 & 16.7 & 15 & 50.0 \\
\hline Child number-2 & 17 & 56.7 & 8 & 26.7 \\
\hline Child number -3 & 7 & 23.3 & 5 & 16.7 \\
\hline Child number-4 & 1 & 3.3 & 2 & 6.7 \\
\hline Term delivery & 28 & 93.3 & 24 & 80.0 \\
\hline \multicolumn{5}{|l|}{ Birth weight } \\
\hline$<2,500 \mathrm{~g}$ & 2 & 6.7 & 2 & 6.7 \\
\hline$\geq 2,500 \mathrm{~g}$ & 28 & 93.3 & 28 & 93.3 \\
\hline
\end{tabular}

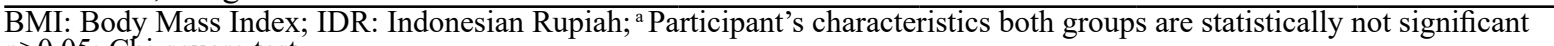
$\mathrm{p}>0.05$; Chi-square test

mother's perspective on less breastmilk (Suwanti \& Kuswanti 2016). This linear to our current study, however, the difference identified after three weeks of consumption (Table 2). The result also showed a similar trend with another study, the difference of breastmilk production in mice between the intervention and control group occurs at least after the $6^{\text {th }}$ day of consumption
(Iwansyah et al. 2017). One possible reason might be because the GMD did not contain Sauropus androgynous leaves only, but the combination of more ingredients such as papaya leaves and mung beans.

Papaya leaves juice stimulates prolactin hormone level, while mung beans, besides having galactagogue effect, also contains thiamine or 
Ngadiarti et al.

Table 2. Breastmilk volume, frequency and duration of breastfeeding

\begin{tabular}{lccc}
\hline \multicolumn{1}{c}{ Variable } & $\begin{array}{c}\text { Intervention group } \\
(\mathrm{n}=30)\end{array}$ & $\begin{array}{c}\text { Control group } \\
(\mathrm{n}=30)\end{array}$ & p-value \\
\hline Breastmilk Volume (ml/day $\pm \mathrm{SD})$ & $622.9 \pm 289.2$ & $507.7 \pm 231.3$ & 0.094 \\
$\quad$ First week & $683.0 \pm 252.4$ & $582.6 \pm 225.4$ & 0.110 \\
Second week & $801.4 \pm 273.3^{\mathrm{b}}$ & $656.2 \pm 214.4$ & $0.026^{\mathrm{a}}$ \\
Third week & $908.5 \pm 271.3^{\mathrm{b}}$ & $756.7 \pm 196.3^{\mathrm{b}}$ & $0.016^{\mathrm{a}}$ \\
$\quad$ & & \\
Fourth week & $14.2 \pm 2.7$ & $15.1 \pm 2.3$ & 0.145 \\
Breastfeeding frequency (times/day $\pm \mathrm{SD})$ & $14.2 \pm 3.1$ & $16.2 \pm 2.8$ & 0.130 \\
$\quad$ First week & $13.8 \pm 2.8$ & $14.2 \pm 2.5$ & 0.534 \\
Second week & $13.0 \pm 2.6$ & $13.8 \pm 2.8$ & 0.273 \\
Third week & & & \\
Fourth week & $18.5 \pm 13.0$ & $14.7 \pm 12.0$ & 0.241 \\
Breastfeeding duration (minutes/day $\pm \mathrm{SD})$ & $18.1 \pm 12.8$ & $14.7 \pm 6.8$ & 0.200 \\
$\quad$ First week & $25.5 \pm 14.8$ & $19.8 \pm 9.7$ & 0.084 \\
Second week & $23.2 \pm 12.1$ & $22.3 \pm 9.4$ & 0.767 \\
$\quad$ Third week & & & \\
Fourth week & &
\end{tabular}

vitamin B1 which converts carbohydrates into energy and reduces stress, as well as triggers oxytocin secretion (Wulandari \& Jannah 2015; Ikhlasiah et al. 2020). Previous studies reported that these effects were due to a dilate blood vessels on the mammary glands and secretory cell proliferation that increase blood flow (Indrayani et al. 2020; Foong et al. 2020). These are related to phytochemical groups' effect on galactopoietic (Mohanty et al. 2014). The GMD polyphenol content was $574 \mathrm{mg}$ after the combined formulation that comparable with a previous study $(8.80 \pm 0.01 \mathrm{mg}$ ) (Iwansyah et al. 2017). Therefore, it modulated the breastmilk production hormones in the lactogenesis and lactation process.

Along with the breastmilk volume, an infant need to be breastfed frequently as necessary without a strict schedule and when this is spontaneous, it prevents breastfeeding problems. The result showed that in the first and second week, breastfeeding frequency was more than in the third (14-16 times/day) and fourth (13-14 times/day). The duration varies according to their suction pattern, where the average was longer in the intervention group (18-23 minutes per breastfeeding) than in the control (14-22 minutes per breastfeeding) (Table 2). Nevertheless, the effect of counselling on breastfeeding frequency and duration was less apparent compared to the GMD group.

The only significant result found was breastmilk volume, where it was measured using Evaporative Water Loss (EWL) on mothers. This method allows a more accurate and precise weighing than on infants due to the unpredictable movement that caused an unstable weighing value. However, it required a strict attention thus mothers did not alter their body weight from consumption, excretion, clothing or physical activity. Another possible reason might be because the mothers had understood how to perform exclusive breastfeeding since they were mostly having the second, third or fourth child (Table 1).

\section{CONCLUSION}

Breastfeeding mothers given the mixture of three galactagogue ingredients mix, namely Sauropus androgynous and papaya leaves, as well as mung beans showed significantly higher breastmilk volume after three weeks of consumption compared to breastfeeding counselling. Considering the fact that the raw materials for this GMD are commonly found and the procedures to prepare it was easy for a household level preparation, this can supplement the breastfeeding counselling program trough 
the Community Health Centre and Community Based Integrated Health Post (Posyandu) to improve exclusive breastfeeding practice in the country, alongside adequate food consumption.

\section{ACKNOWLEDGEMENT}

The authors are grateful to Mr. Joko Sulistyo, Directors of Health Polytechnics of Jakarta II and Directors of the Maternity Hospital of Kebayoran Lama Community Health Centre for their permission, support and cooperation. The authors are also grateful to Mrs. Betty Yosephin from Health Polytechnic for the suggestions provided to improve this study.

\section{AUTHOR DISCLOSURES}

No potential conflict of interest relevant to this article was reported.

\section{REFERENCES}

Fanzo J, Hawkes C, Udomkesmalee E, Afshin A, Allemandi L, Assery O, Baker P, Battersby J, Bhutta Z, Chen K et al. 2018. 2018 Global nutrition report: Shining a light to spur action on nutrition. https://doi. org/10.1063/1.4759115

Foong SC, Tan ML, Foong WC, Marasco LA, Ho JJ, Ong JH. 2020. Oral galactagogues (natural therapies or drugs) for increasing breast milk production in mothers of non-hospitalised term infants. Cochrane Database Syst Rev (5). https://doi. org/10.1002/14651858.CD011505.pub2

Galipeau R, Dumas L, Lepage M. 2017. Perception of not having enough milk and actual milk production of first-time breastfeeding mothers: Is there a difference? Breastfeed Med 12(4):210-217. https:// doi.org/10.1089/bfm.2016.0183

Ghasemi V, Kheirkhah M, Vahedi M. 2015. The effect of herbal tea containing fenugreek seed on the signs of breast milk sufficiency in iranian girl infants. Iran Red Crescent Med J 17(8):1-6. https://doi.org/10.5812/ ircmj. 21848

Government Regulation of Republic Indonesia number 33 in 2012 about Exclusive Breastfeeding Practices. President of Republic of Indonesia. http:// hukor.kemkes.go.id/uploads/produk hukum/PP\%20No.\%2033\%20ttg\%20

Pemberian\%20ASI\%20Eksklusif.pdf [Accessed on 21th June 2021].

Ikhlasiah M, Winarni LM, Poddar S, Bhaumik A. 2020. The effects of papaya leaf juice for breastfeeding and working mothers on increasing prolactin hormone levels and infant's weight in Tangerang. Enfermeria Clinica 30:202-205. https:// doi.org/10.1016/j.enfcli.2019.11.054

Indrayani D, Shahib MN, Husin F. 2020. The effect of katuk (Sauropus androgunus (L) Merr) leaf biscuit on increasing prolactine levels of breastfeeding mother. KEMAS: Jurnal Kesehatan Masyarakat 16(1): 1-7. https://doi.org/10.15294/kemas. v16i1.11324

Iwansyah AC, Damanik MRM, Kustiyah L, Hanafi M. 2017. Potensi fraksi etil asetat daun Torbangun (Coleus amboinicus L.) dalam meningkatkan produksi susu, bobot badan tikus, dan anak tikus. J Gizi Pangan 12(1):61-68. https://doi.org/10.25182/ jgp.2017.12.1.61-68

Kuchenbecker J, Jordan I, Reinbott A, Herrmann $\mathrm{J}$, Jeremias T, Kennedy G, Muehlhoff E, Mtimuni B, Krawinkel MB. 2015. Exclusive breastfeeding and its effect on growth of Malawian infants: Results from a cross-sectional study. J Paediatr Child Health 35(1): 14-23. https://doi.org/10.11 79/2046905514Y.0000000134

Laksono AD Wulandari RD, Ibad M, Kusrini I. 2021. The effects of mother's education on achieving exclusive breastfeeding in Indonesia. BMC Public Health 21(1):16. https://doi.org/10.1186/s12889-02010018-7

Liu H, Hua Y, Luo H, Shen Z, Tao X, Zhu X. 2015. An herbal galactagogue mixture increases milk production and aquaporin protein expression in the mammary glands of lactating rats. Evid Based Complement Alternat Med 2015:1-6. https://doi. org/10.1155/2015/760585

Mediastari AAPA. 2020. Local wisdom traditional medicine for the health and beauty of postpartum mother in Denpasar City, Bali Province, Indonesia. International Journal of Health \& Medical Sciences 3(1):65-71. https://doi.org/10.31295/ijhms.v3n1.149 
[MoH RI] Ministry of Health of Republic of Indonesia. 2018. Basic Health Research (RISKESDAS). Jakarta (ID): MoH RI.

Mohanty I, Senapati MR, Jena D, Behera PC. 2014. Ethnoveterinary importance of herbal galactogogues - a review. Vet World 7(5):325-330. https://doi.org/10.14202/ vetworld.2014.325-330

Newton ER. 2018. Lactation and breastfeeding. Gabbe's obstetrics essentials: Normal $\&$ problem pregnancies. https://books. google.co.id/books?hl=id\&lr=\&id= opx YDwAAQBAJ\&oi=fnd \&pg=PA $171 \& d q=$ lactation + and + breastfeedi $\mathrm{ng} \& \mathrm{ots}=\mathrm{NrnHc} 5 \mathrm{cE} 4 \mathrm{C} \& \mathrm{sig}=5 \mathrm{IIJ} 0 \mathrm{q}$ xaCPB-tDjaoMPrLCzTn_s\&redir es $\mathrm{c}=\mathrm{y} \# \mathrm{v}=$ one page $\& \mathrm{q}=1$ actation $\% 2 \overline{0}$ and $\% 20$ breastfeeding $\& \mathrm{f}=$ false [Accessed 20th June 2021].

Nguyen PH, Kim SS, Nguyen TT, Hajeebhoy N, Tran LM, Alayon S, Ruel MT, Rawat R, Frongillo EA, Menon P. 2016. Exposure to mass media and interpersonal counseling has additive effects on exclusive breastfeeding and its psychosocial determinants among Vietnamese mothers. Matern Child Nutr 12(4):713-725. https:// doi.org/10.1111/mcn.12330

Nuzrina R, Roshita A, Basuki DN. 2016. Factors affecting breastfeeding intention and its continuation among urban mothers in West Jakarta: A follow-up qualitative study using critical point contact for breastfeeding. Asia Pac J Clin Nutr 25(Suppl 1):S43-S51. https://doi.org/10.6133/apjcn.122016.s10

Nyqvist KH, Häggkvist AP, Hansen MN, Kylberg E, Frandsen AL, Maastrup R, Ezeonodo A, Hannula L, Koskinen K, Haiek LN. 2012. Expansion of the ten steps to successful breastfeeding into neonatal intensive care: Expert group recommendations for three guiding principles. J Hum Lact 28(3):289-296. https://doi. org/10.1177/0890334412441862

Pillay J, Davis TJ. 2020. Physiology Lactation. Treasure Island (USA): StatPearls Publishing.

Pinem SB, Ginting AB, Simamora L. 2019. Pengaruh konsumsi biskuit katuk, dan pijat oksitosin terhadap keberhasilan pemberian asi eksklusif pada ibu menyusui di Puskesmas Simalingkar tahun 2019. Dinamika Kesehatan Jurnal kebidanan dan Keperawatan 10(2):856-866. https://doi. org/10.33859/dksm.v10i2.492

Sakka AE, Shimil MSE, Ibrahim SH. 2014. Effect of implementing breastfeeding promotion program in neonatal intensive care unit on newborn weight and breastfeeding practices. Int J Clin Pediatr 3(2):40-45. https://doi.org/10.14740/ijcp159w

Santoso U. 2016. Katuk, tumbuhan multi khasiat. Bengkulu (ID): Badan Penerbit Fakultas Pertanian (BPFP) UNIB.

Scanlon KS, Alexander MP, Serdula MK, Davis MK, Bowman BA. 2002. Assessment of infant feeding: the validity of measuring milk intake. Nutrition Reviews 60(8):235-251. https://doi. org/10.1301/002966402320289368

Sulaiman Z, Liamputtong P, Amir LH. 2018. Timing of return to work and women's breastfeeding practices in urban Malaysia: A qualitative study. Health Soc Care Community 26(1):48-55. https://doi. org $/ 10.1111 /$ hsc. 12460

Suwanti E, Kuswati K. 2016. Pengaruh konsumsi ekstrak daun katuk terhadap kecukupan asi pada ibu menyusui di Klaten. Interest: Jurnal Ilmu Kesehatan 5(2):132-135. https://doi.org/10.37341/interest.v5i2.42

Tao XY, Huang K, Yan SQ, Zuo AZ, Tao RW, Cao H, Gu CL, Tao FB. 2017. Pre-pregnancy BMI, gestational weight gain and breastfeeding: A cohort study in China. Public Health Nutr 20(6):1001-1008. https://doi. org/10.1017/S1368980016003165

Walters D, Horton S, Siregar AYM, Pitriyan P, Hajeebhoy $N$, Mathisen R, Phan LTH, Rudert C. 2016. The cost of not breastfeeding in Southeast Asia. Health Policy and Planning 31(8):1107-1116. https://doi.org/10.1093/heapol/czw044

Wulandari DT, Jannah SR. 2015. Pengaruh pemberian sari kacang hijau pada ibu nifas dengan kelancaran produksi asi di BPM Yuni Widaryanti, Amd. Keb Sumbermulyo. Eduhealth 5(2):94-101. 